NBER? WORKING PAPER SERIES

CHANGE AND PROGRESS IN

CONTEMPORARY MORTGAGE MARKETS

Edward J. Kane

Working Paper No. 1478

NATIONAL BUREAU OF ECONOMIC RESEARCH

1050 Massachusetts Avenue

Cambridge, MA 02338

October 1984

The research reported here is part of the NBER ${ }^{\prime} s$ reseirsh program

in rinaneial Markets and Monetary Econonics. Any opinions

expressad are those of the author and not those of the National. Burealu of Economic Research. 
Change and Progress in Contemporary Mortgage Markets

\section{ABSTRACT}

Changes in political attitudes toward subsidizing mortgage loans and in technologies for transacting mortgage loans and for pooling and refinancing individual mortgage contracts threaten to remake the face of U.S. mortgage markets. This paper focuses on economic-efficiency benefits embodied in narrowed interest-rate spreads and on distributional effects for different market participants created by three categories of change: changing strategies for controlling implicit federal guarantees; continuing evolution in the character of mortgagebacked securities; and expanding electronic mortgage-application networks. It proves instructive to classify these effects further according to whether they are transitional or permanent in nature and whether they are technologically driven or filtered through the political process.

The analysis emphasizes that technological change is reducing the controllability of aggregate subsidies associated with longstanding patterns of providing implicit and explicit federal guarantees for the liabilities of important mortgage-market participants and discusses several proposals for bringing the market value of these guarantees back under administrative control.

Edward 3. Kane Department of Economics

Ohio Sta te University 343 Hagerty Hall

Columbus, Ohio 43210 (614)-422-8708 
September 26, 1984

\title{
CHANGE AND PROGRESS IN CONTEMPORARY MORTGAGE MARKETS
}

\author{
Edward J. Kane*
}

Whenever the landscape of our lives changes rapidly, it is helpful to contemplate two texts. The first is an aphorism enunciated almost 2,500 years ago by the Greek philosopher Heraclitus: "Nothing is permanent except change."

Pursuing the psychological reverberations of this thought, we may observe that the more rapid the rate of change becomes, the more deeply stressed and disoriented disadvantaged participants feel. Feelings of unsettlement experienced in confronting the unfamiliar are the distinctive fare of science fiction. In this genre, writers have speculated repeatedly about how socially disruptive it would be if scientists were to discover how to accelera te the rate of technological change.

Reinforcing its readers' instinctive fear of a lurking unknown, this literature often advances the view that accelerated technological change would evoke undesirable adjustments in lifestyle and environment that would dramatically worsen the human situation. However, for the long run, the history of scientific and technological achievement supports the opposite result. If Heraclitus could be transported to our time, he would be literally dazzled by advances in technology that, by freeing mankind from slaving to fulfill its most basic requirements for survival, have sharply expanded the horizons of human activity. This thought leads conveniently into our second text (one that in the 1950s, as a television spokesman for General Electric, Ronald Reagan used to preach every Sunday night): "Progress is our most important product."

*Everett D. Reese Professor of Banking and Monetary Economics, The Ohio State University and Research Associate, National Bureau of Economic Research. The author wishes to thank HUD for financial support and Ann Dougherty, Jack Guttentag, Joseph Ifumphrey, George Kaufman, Anthony Sanders, David Seiders, Robert Van Order, and Kevin Villani for helpful comments. Opinions expressed are those of the author and should not be construed to represent those of the NBER. 
Of course, not all change is progressive. Contemporary adjustments in mortgage markets are driven by two conceptually distinct forces: the shifing winds of political consensus and the steadier blast of technological change. Although the long-run effects of technologically driven change are progressive, politically driven change is oriented toward the short run and is of ten regressive.

\section{Politically Filtered Changes}

What we may call politically filtered changes in mortgage markets represent economic responses to changes in the flow of implicit and explicit federal taxes and subsidies to housing finance. Historically, various federal agencies have sought to help mortgage markets by smoothing the interest-rate cycle, underpricing deposit-insurance guarantees for maturity and credit risk undertaken by specialized mortgage lenders, imposing housing-related deposit-rate ceilings and asset restrictions on thrift institutions, guaranteeing cash flows on mortgage instruments, and subsidizing interest rates on mortgage loans for low-income housing. During the 1980 s, public policy has aimed at eliminating or at least reducing most of these subsidies.

We may identify two watershed changes, with several more still under discussion. The first is the October 6, 1979 reorientation of Federal Reserve antiinflationary monetary policy. Since that date, the Fed has fought inflation in ways that have greatly increased the volatility of market interest rates. Prior to this date, Fed efforts to smooth short-run changes in interest rates served to reduce the exposure of short-borrowing, long-lending mortgage lenders (i.e., thrift institutions) to large overnight declines in the market value of their net worth. ${ }^{1}$ The second watershed change was the staged abandonment of the two-pronged regulatory strategy of simultaneously requiring thrift institutions to specialize in

mortgage lending and trying to beef up their profit margins by imposing a discriminatory system of ceilings on the explicit interest rates they and other 
deposit institutions could pay on deposits. This change in strategy was first embodied in the Depository Institutions Deregulation and Monetary Control Act of 1980, which liberalized asset powers for thrift institutions and established an interagency committee to deregulate deposit-rate ceilings. The Garn-St Germain Depository Institutions Act of 1982 moved both legs of the new strategy forward by authorizing money market deposit accounts and further relaxing restraints on thrift-institution diversification. As documented in George Kaufman's and David Seiders' pieces for this symposium, thrift institutions' pursuit of opportunities to restructure their balance sheets only temporarily reduced these institutions' relative role in financing the flow of new mortgages.

Other subsidy-reducing proposals under active consideration include:

1. the possibility of introducing new restrictions on the guarantee and mortgage-banking authority of Fannie Mae, Ginnie Mae, and Freddie Mac;

2. the possibility of explicitly or implicitly repricing federal deposit insurance to reduce the effective subsidy to maturity mismatching and default risk inherent in an insured thrift institution's mortgage lending.

My reading of the bureaucratic and legislative record indicates that (except for the 1984 passage of a tax-law provision to subject Freddie Mac income to federal income taxation) the first proposal is at least temporarily stymied. The second proposal has been embodied in FSLIC and FDIC requests for authority to set riskrated insurance premia and naive regulatory efforts to impose lower insurance limits on brokered deposits and to persuade insured thrift institutions to switch their new lending from fixed-rate mortgages (FRMS) to adjustable-rate mortgages (ARMs). For many S\&Ls, the FHLB's signalling that its examiners would view ARM lending favorably made ARMs the vehicle of choice for exploiting depositinsurance subsidies to mortgage lending. The unintended effect of this FSLIC effort to promote ARMs has been to encourage the sharpest of its clients to transform straightforward interest-volatility risk into exotic forms of credit risk. 
Observable shifts in public policy respond to lobbying pressures against which it is feasible to organize an effective political counterattack. The profitability of managing the industry's lobbying efforts may explain why spokespersons for the traditional community of housing lenders tend to exaggerate the long-run effects of government subsidies on the profitability of mortgage lending. In effect, they advertise political action as both the cause and the remedy for all industry problems. While this may maximize political action and industry contributions to trade-association coffers, economic analysis suggests that, for individual managers, it is a distinctly unhelpful perspective. It directs their attention to battling collectively to undo the effects of change rather adapting individually to its consequences.

Promoters of lobbying efforts fail to appreciate how quickly and how thoroughly in a competitive industry the benefits of subsidies dissipate over time. The age-old problem with striving to target subsidies to producers of any governmentally approved good or service -- including that of housing finance -- is that market entry by unintended beneficiaries and competition among the intended beneficiaries tends to shift the subsidies away to other parties: specifically to customers and to suppliers of the factor services employed in producing and distributing the subsidized products. Even if the gcvernment had intended subsidies to mortgage lenders to stay with these lenders (which is doubtful), it could not put handles on them. As a result, price competition has spilled these subsidies out of the income statements of specialized lenders into the economy at large. Unless one recognizes that the fragility of market power prevents subsidies from staying put, it is hard to understand why a group as heavily subsidized ex ante as specialized mortgage lenders could have proved so spectacularly unprofitable ex post over the last 18 years.

For mortgage lenders, the bright side of this coin is that reductions in these subsidies ought to be shifted, too. Because the shifting process figures to reduce 
boih the asgregate value of new investments in housing and the amount of mortgage debt in the economy, in the short run specialized mortgage lenders can best maintain profit margins by diversifying their activities into additional lines of financial service. To do this most effectively, industry managers must understand and make friends with the technologically driven changes that are currently unfolding in contemporary markets for financial services.

\section{Technologically Driven Changes}

During the last decade, technological change in the methods used to produce and distribute credit in U.S. mortgage markets has been both extraordinarily rapid and extraordinarily wide-ranging. Innovations have occurred in the rights and duties incorporated into mortgage contracts, in direct and indirect opportunities for taking and unwinding positions in these contracts, and in the activities undertaken by contracting parties and their agents in arranging deals. So that we may have a label for each type of innovation, we may call them the destandardization, the securitized stripping, and the electronification of mortgage loans. The common effect of all three developments has been progressive: to perfect interregional and interinstitutional competition at all stages of making and financing mortgage loans. The effect is to reduce the implicit and explicit resource costs of lining up and transacting the best deal possible. Secular reductions in transactions costs have sharply increased the transactional efficiency of mortgage markets, reducing the cost of taking margined and short positions in mortgage instruments and enabling market participants to adjust their pre-existing balance sheets to changes in investment opportunities more quickly and more completely than ever before. 2

By lowering barriers to entry into local mortgage markets, this increase in transactional efficiency has fostered an invasion of these markets by extraregional and other nontraditional competitors. This has had three observable effects. First, 
it has lowered the costs of mortgage contracting and narrowed the spread between mortgage interest rates and yields on Treasury and corporate bonds of similar duration. The development of electronic methods of mortgage banking and organized forward and secondary markets for whole and stripped mortgage loans has forged new and tighter arbitrage links between movements in interest rates in informal markets for mortgages and movements in rates of returns in organized markets for securities of various types. Second, it has restructured and relocated industry work flows, establishing a more-extensive pattern of specialization that in many cases reduces the flow of quasi-rents to traditional market participants from personal expertise and localized transactional networks they have built up over the years.

Third, it has assisted the destandardization or customization of the contract for home loans. Customized elements include graduated payment schedules (including first-year buydowns by sellers), prepayment options, assumability privileges, lines of credit conditioned on homeowner equity, equity sharing, and various kinds of adjustable-rate triggers and caps on the level to which adjustable rates or monthly payments may escalate. ${ }^{3}$ In exchange for an appropriate adjustment in contract interest rates, other contract terms can be tailored either to eliminate or to counterbalance portfolio risks of particular concern to the borrowing or the lending party in the mortgage contract. For individual lending institutions, forward and secondary markets facilitate a cafeteria-style offering of heterogeneous contract forms in two ways. First, these markets provide base prices from which lenders may conveniently calculate a market value for various customized contract features that particular classes of borrowers find attractive. Second, opportunities to sell uncongenial contracts into these markets (particularly improved opportunities for selling off relatively liquid FRMs) permit an institution to put a wider range of loan contracts into its servicing portfolio than concern for economically controlling its exposure to interest-rate risk might let it retain in its investment portfolio. 
Technological Innovations in the 1980s.

During the early 1980s, partly because of pressure from deposit-insurance agencies, adjustable-rate home loans have begun to push fixed-rate loans into the background. This is especially true of the market for conventional mortgages, where since November, 1983 ARMs' percentage of the flow of new loans has exceeded 50 percent. This passage has been facilitated by two technologically driven innovations: collateralized mortgage obligations and electronic mortgageapplication networks.

Although CMOs based on ARMs are now only in the planning stage, CMO technology has facilitated the spread of ARMs in two ways. First, because it increases the liquidity of FRMs, this technology makes it easier for a local lender to emphasize adjustable-rate lending without depriving its customers of an effective choice between ARM and FRM financing. Preserving this choice has neutralized consumerist fears that held up the introduction of ARMs in many jurisdictions during the early 1970s. Second, the success of the CMO as a vehicle for unloading FRMs creates a parallel demand for forms of mortgage-backed securities that could be based on ARMs. To keep their loans easily absorbable into future ARM pools, lenders have an incentive to limit the variety of ARM triggers, adjustment periods, and caps to conform to developing industry standards.

Electronic mortgage-application networks allow adjustable-rate lenders to offer funds over a wider region. They also make it easier for a would-be borrower (perhaps with the assistance of an associated expert or software package) to compare alternative contracts. Taken together, these innovations provide a market solution to the problem of information overload in comparing the terms of customized mortgage contracts that leads Guttentag (1983) to declare a need for industry self-regulation to control expansion in mortgage designs. 
Collateralized Mortgage Securities. With aggregate mortgage debt approaching 1.5 trillion dollars, it is not surprising that securities firms would strive to win themselves a piece of the action. To make mortgage-backed securities attractive to a broad range of institutional investors, three serious conceptual problems had to be solved:

1. How to aggregate (or "package") cash flows from a collection of diverse low-denomination mortgage loans into an intelligible highdenomination asset pool;

2. How to relieve investors in these pools of the need to evaluate the credit risk of the individual mortgages in the pool;

3. What to do about the risk that optional borrower prepayments may drastically shorten the effective maturity of the pool.

The first generation of mortgage-backed securities (MBS) solved the first two problems without explicitly addressing the third. Called mortgage participations or pass-through securities, these instruments promise to pass along all payments custodians receive from servicers of the pooled contracts, with investors guaranteed against servicer nonperformance by an ownership claim on the mortgage pool and against borrower default and delinquency by private mortgage insurers and/or one of the big-five federal housing-credit agencies or agency-corporations. These guarantors are the Federal Home Loan Mortgage Corporation ("Freddie Mac"), the Federal National Mortgage Association ("Fannie Mae"), the Government National Mortgage Association ("Ginnie Mae"), the Federal Housing Administration (The FHA), and the Veterans Administration (the VA).

However, the unavailability of call protection limited the extent to which passthroughs could appeal to insurance companies and pension funds. These longterm investors were not excited about acquiring participation certificates which 
required them to take a short position in a call option owned by mortgage borrowers. They had reservations not just about the unpredictability of prepayments, but especially about the likelitood that they would be concentrated in periods when interest rates would be low, so that the proceeds would have to be reinvested at unfavorable yields. The collateralized mortgage obligation (CMO) is a second-generation mortgage-backed security designed specifically to permit different investors to take title to the early and late cash flows generated by the pool of mortgages serving as collateral (Villani, 1983). In that it involves stripping and repackaging the cash flows on a primary security, a CMO parallels the cutely nicknamed zero-coupon "animal" securities that investment-banking firms fashion from ordinary Treasury bonds. Packagers of CMOs sell investors, not direct participations in the proceeds of a mortgage pool, but segregated claims to the early, intermediate, and distant cash flows that the underlying pool of mortgages (or mortgage participation certificates) actually throws off.

Pioneered by Freddie Mac in June 1983, the typical CMO designates three or four classes of bonds, scheduled to be paid off serially. Until the first or shortest class is fully retired, its holders receive all principal payments thrown off by the pool. Only then do principal payments accrue to the second maturity class. Only after both of these classes have been paid off, do principal payments begin to flow to the third class, and so on. Usually, all classes pay interest semiannually, although sometimes the longest class merely accrues its interest until all fasterpaying classes have been retired.

Earmarking flows of principal payments for holders of the faster-paying classes enlists into the direct provision of home finance institutional investors whose hedging interests or maturity habitats are short-term. At the same time, it serves to lengthen the duration (or average futurity) of the late-paying securities 
and to shift some of the burden of borrowers' prepayment options from long-term to shorter-term investors. Figure I shows that the relative shares purchased by deposit institutions, insurance companies, and pension funds in the three classes of Freddie Mac's first CMO correspond broadly with conventional wisdom about the distribution of these firms' marginal hedging interests.

In 1983, approximately $11 \mathrm{CMO}$ issues were floated publicly, amounting to about $\$ 4$ billion in the aggregate. At least $\$ 6$ billion more were issued in the first five months of 1984. Table I disaggregates the first $28 \mathrm{CMO}$ issues by the type of institution doing the packaging. Table 2 disaggregates these same issues by the type of collateral whose cash flows are being stripped.

Except that it maintains no net-worth account (which prevents it from accepting any interest-rate risk) and issues its liabilities into securities markets rather than directly to depositors, a CMO packager operates very much like an S\&L. It supports a portfolio of mortgages with liabilities of varying maturity. CMOs issued by a government conduit are effectively government-guaranteed. Although CMOs issued by private conduits are not guaranteed directly, they are backed by mortgage assets that are at least partly insured by one of the government mortgage corporations (usually GNMA). Also, because CMO liabilities are securities rather than deposits, their minimum denomination is probably never smaller than $\$ 25,000$ and their average denomination is typically higher rather than lower than the average denomination of the mortgages they finance. In fact, to qualify for an FHLMC or FNMA guarantee, the value of the individual mortgages in a CMO must not exceed a ceiling of approximately $\$ 114,000$.

As this analogy should make clear, any S\&L could in principle package its mortgage portfolio into a CMO and even issue CMOs in small denominations to its retail customers. Because S\&Ls' average yield on their mortgage portfolios 
Figure 1

Institutional Profile of Investors in the Three Series of FHLMC's

First Collateralized Mortgage Obligation (CMO)

(June 1983)

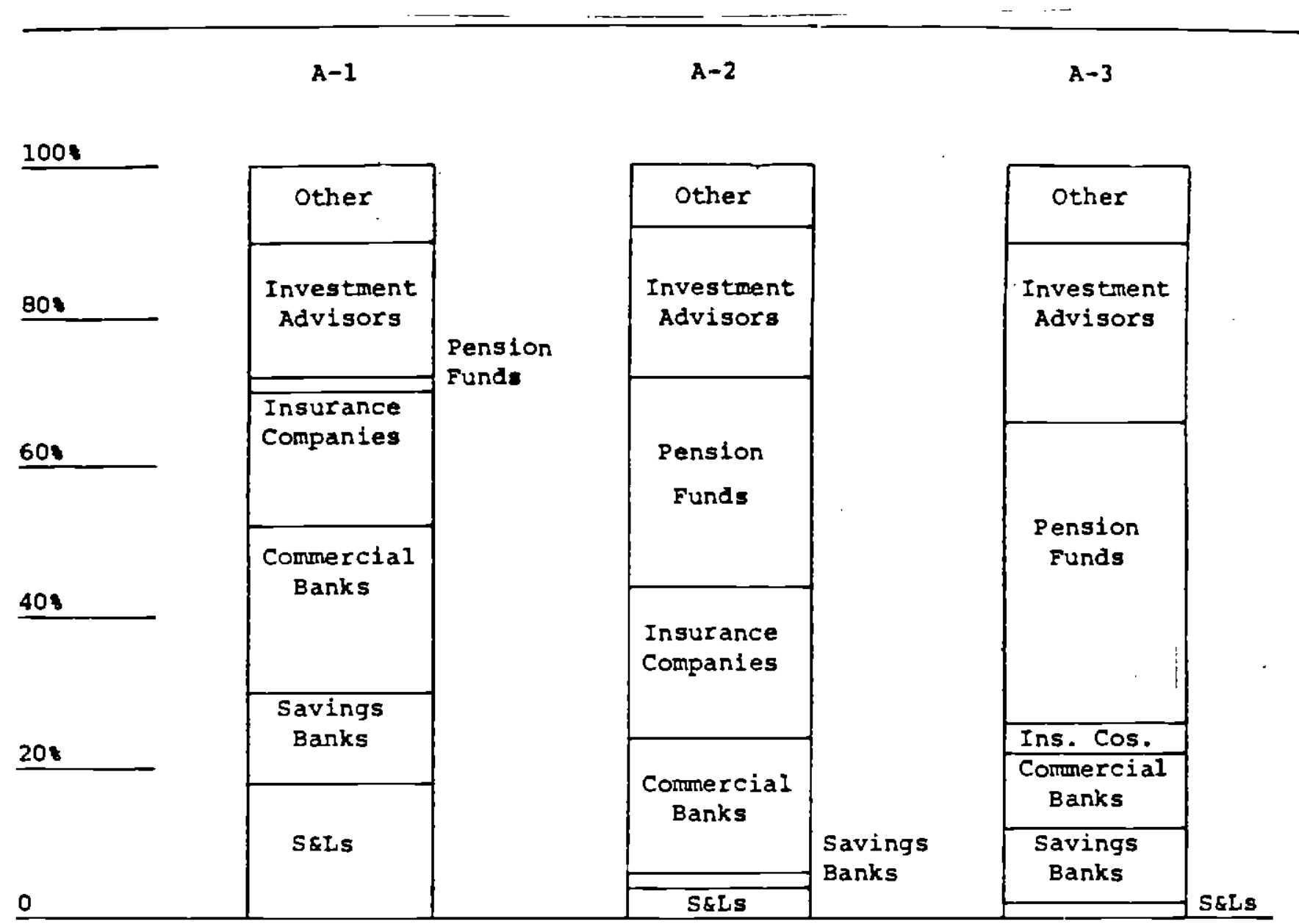

Source: Federal Home Loan Mortgage Corporation

Notes:

1. "Other" includes trust companies, broker/dealers, credit unions, corporations, and individuals.

2. The fastest-paying security is labelled $A-1$, the slowest $A-3$. 


\section{Table 1}

First Twenty-eight Issues of Collateralized Mortgage Obligations, Disaggregated by Type of Institution Doing the Packaging

\begin{tabular}{|c|c|c|c|}
\hline-- & $\begin{array}{c}\text { Number of } \\
\text { Issuers }\end{array}$ & $\begin{array}{c}\text { Number of } \\
\text { Issues }\end{array}$ & $\begin{array}{c}\text { Dollar } \\
\text { Amount } \\
\text { (in billions) }\end{array}$ \\
\hline Freddie Mac & 1 & 4 & 2.93 \\
\hline Builder Bonds & 4 & 11 & 1.75 \\
\hline Private Conduits & 9 & 13 & 5.64 \\
\hline $\begin{array}{l}\text { Financial Corp. } \\
\text { Insurance Companies } \\
\text { Mortgage Bankers } \\
\text { Dealer-Sponsored Issuers } \\
\text { Thrif ts }\end{array}$ & $\begin{array}{l}(1) \\
(2) \\
(3) \\
(3) \\
(0)\end{array}$ & & \\
\hline Totals: & 14 & 28 & 10.32 \\
\hline
\end{tabular}

Source: Kevin Villani, "Innovations in the Mortgage Markets," Everett D. Reese-Park National Bank Distinguished Lectures, Columbus, Ohio, May 24, 1984. 
Table 2

First Twenty-Eight Issues of Collateralized Mortgage Obligations, Disaggregated by Type of Collateral Employed

\section{Type of Collateral}

1. Pools of Whole Mortgage Loans Only

a. Conventional Mortgages

b. Conventional and FHA/VA mortgages

2. Pools Using Mortgage-Backed Securities

8. Conventional Mortgages, FNMA MBS, and FHLMC participation certificates

b. FNMA MBS and GNMA securities

c. GNMA securities

Number of
Issuers

2

1

1

1

11

16
Number of Issues

5

1

1

0.08

1.25

5.44

20

28

10.32

Source: Same as Table 1

*This row includes the four FHLMC issues 
currently lies well below today's roughly 14.25 percent yield on new fixed-rate mortgages, such a CMO would probably need to be issued at a discount from par. Compared to CMOs issued at par, a discount CMO would have the advantage of providing greater call protection for all classes of investors than a nondiscount issue.

But because only its deposit liabilities are explicitly guaranteed (by the Federal Savings and Loan Insurance Corporation or FSLIC), an S\&L's CMOs would be subject to credit risk. Before they could be designated as investment-grade securities, this credit risk would in practice have to be insured by a credible party or rated formally by Moody's or Standard and Poor's. Under state prudent-man rules and federal pension-fund legislation, CMOs that are not rated as investmentgrade could be held only in limited amounts by individual insurance companies and pension funds. However, until the FSLIC clarified how it would settle the claims of CMO holders in the event that an issuing S\&L went bankrupt, private insurance companies and credit-rating firms could not analyze all relevant contingencies. Without knowing how the FSLIC would treat holders of discounted CMOs in a Iiquidation, they could not prudently undertake to guarantee or rate an S\&L's CMO. In connection with a CMO proposed by Guardian Savings and Loan of Houston, Standard \& Poor's began to negotiate with the FSLIC in late 1983. In early 1984 they agreed upon a tentative formula for use in marking CMOs to market in the event of the liquidation of an S\&L issuer (LaGesse, 1984b). Because the FDIC has not taken a position on the issue and because the FSLIC has reserved the right to challenge CMOs that promise to pay a premium to bondholders if the bond agreement is liquidated, Standard and Poor's still will not rate CMOs from FDICinsured institutions or from S\&Ls that stipulate redemption at a premium in the case of insolvency.

Given how far underwater the S\&L industry is sinking, the FSLIC might want to investigate issuing its own CMOs and mortgage passthroughs, which could be 
backed up by pools of mortgage loans it would take over in closing insolvent institutions. In many cases, liquidating an S\&L via a CMO may offer a cheaper method of resolving its failure than making merger-assistance payments and regulatory concessions to an acquirer that is reluctant to take on the burden of the failing firm's problems.

Electronic Mortgage-Application Networks. CMOs and other MBS may be regarded as establishing more-intricate connections between mortgage originators and ultimate suppliers of mortgage capital. Electronic mortgage-application networks complement MBS by forging new links between homebuyers and mortgage originators. Using realtors as points of personal contact, these networks computerize and "telecommunicate" one or more steps in the process of shopping and negotiating for a home loan.

The pioneer network is Shelternet, which is owned by First Boston Corp. and began operation in July 1983. At last report, Shelternet had 40 participating lenders and serviced 125 originators in 30 states. Its services run the gamut from maintaining lists of mortgage designs and contract interest rates currently offered by participating lenders (so far, all of these are thrift institutions) through taking and processing loan applications and committing lender funds. Two networks that limit themselves merely to mortgage listing are: RKI Databanks and the Realtors National Mortgage Access System (Rennie Mae). In early 1984, other full-service networks were just beginning to come on-line.

Quantitatively, electronic mortgage markets are still minor players. In its first nine months, Shelternet processed about 1,000 applications and closed about 500 mortgages that in the aggregate were worth only about $\$ 3.5$ million dollars (LaGesse, 1984a). However, by April 1984, Shelternet was handling almost $\$ 100$ million worth of applications a month. The outlook for these networks is extremely favorable. They facilitate intelligible disclosure of relevant mortgage information. Also, as long as realtors are clever enough to find a label for loan-origination fees 
that does not violate the Real Estate Settlement Practices Act, these networks permit realtors to upgrade their service package and to capture income that would otherwise accrue to local lenders or mortgage-banking firms. However, this activity might make them subject as "arrangers of credit" to the Fed's Regulation $z$.

\section{Winners and Losers From Mortgage-Market Innovations}

\section{Effects on Mortgage Lenders}

The evolving division of labor in mortgage finance puts a premium on a firm's capacity to recognize and to adapt to changing business opportunities and greatly complicates the work of every regulatory agency whose mission requires it to influence the price or quantity of mortgage credit.

Over time, electronic and abstract derivative forms of mortgage contracting are displacing familiar product forms and face-to-face systems for distributing them. At the same time that this process reduces the profitability of traditional activities, it opens up opportunities to produce, distribute, and finance the emergent contract forms. Unfortunately, traditional mortgage lenders typically see the darker side of the process more clearly than the brighter one. They tend to be put off emotionally by the transitional costs of adjusting their skills, capital, and operating procedures to the evolving requirements of the marketplace. In an era of rapid change, resistance to jettisoning organization structures and contract limitations that proved successful in the past makes traditional mortgage lenders slow to recognize emerging opportunities for arbitraging differences in profitability between new and old ways of doing things. This lag in adaptation by traditional players encourages nontraditional players - in the form of mortgage-pooling firms such as Freddie Mac and securities firms such as Salomon Brothers, First Boston, and Merrill Lynch -- to expand their role in mortgage financing.

Specialized mortgage lenders have traditionally viewed mortgagor and property evaluation, contract design, loan processing, funds commitrnent, mortgage 
servicing, and mortgage financing as activities to be performed under their direct supervision. When activities are performed jointly in-house rather than contracted out to specialists, the implicit prices of component services are not separately observable. Only the bundled price is directly observed. Advances in telecommunications and in forward and secondary markets let outside observers unbundle the prices of the component activities of mortgage lending. They allow individual activities to be performed in different combinations, whose publicly quoted prices may be stripped apart to price individual functions separately. This stripping and explicit pricing separates activities in these submarkets and facilitates entry from extraregional functional specialists. This entry tends to eradicate any pockets of monopoly power in local markets for originating and servicing mortgages. At the same time, it squeezes ex ante returns for financing mortgage down to the level of securities yields generally. Taken together, these changes encourage realtors to guide homebuyers through the loan-application, contract-design, and loan-processing stages and encourages traditional mortgage lenders both to concentrate on the mortgage-origination and mortgage-servicing functions and to price these services closer to operating costs.

In principle, investment-banking houses, brokerage firms, and commercial banks have back-office capabilities and delivery systems that make it relatively easy for them to perform the so-called conduit function of buying up mortgages in the secondary market and of packaging (or transforming) them into mortgagebacked securities (MBS). On the marketing or distribution side, these same firms are well-situated both to identify potential customers (household as well as institutional investors) and to advise these customers as to the types of mortgagebacked securities that would best fit their portfolio objectives. Their major problem is to provide from their own credit standing or to secure from a third 
party credible guarantees of promised cash flows. In practice, FHLMC has dominated the conduit function. ${ }^{4}$ In early 1984, highly rated private conduits for CMOs (specifically Sears Mortgage Securities Corp., General Electric Credit Corp., Residential Funding Corp., Norwest Mortgage Co., and FCA Mortgage Securities) began to make substantial plays. On the underwriting side, pre-existing limitations on deposit institutions' investment-banking powers have helped to deflect the bulk of the underwriting business so far to securities firms. Deposit institutions' principal cut of the MBS business has been to earn fees as servicers or as custodians of the mortgage pool.

Mortgage-backed securities collateralized by mortgage pools that are assembled by builders (so-called "builder bonds") promise to shift additional opportunities to make mortgages on new homes from deposit institutions to builders' mortgagebanking subsidiaries and to securities firms. Builder bonds permit construction firms to designate sales of completed homes as installment sales for tax purposes. This means that builders are taxed as the owner makes amortization payments rather than at the time of sale. The proceeds of the bonds enable builders to enjoy the cash flow of an outright sale, while taking buyers' mortgages defers most of the tax liability to future years. Because of the tax savings, a builder can afford to offer a below-market interest rate to buyers of his products. U.S. Home Corp. and Pulte Inc. have had their own builder-bond program for several years. Consortiums launching multibuilder issues include: the Ryland Group of Columbia, Maryland; American Southwest Financial Corp.; and the National Association of Home Builders (Schellhardt, 1983). More recently, investment-banking houses (Kidder, Peabody, \& Co. and Salomon Brothers, Inc.) have developed nonconsortium programs for smaller builders (LaGesse, 1984C). Unless the installment-sales tax option is changed, if thrift institutions don't want to be squeezed out of new-home financing in the long run, they may have to establish themselves as developers. 
At the same time that entry into mortgage markets by builders and securities firms is squeezing margins in mortgage lending, the development of electronic systems for marketing mortgage loans through real-estate brokers is giving nonlocal lenders a growing role in mortgage origination and mortgage servicing. To meet this competition, thrift institutions may have to add real-estate brokerage to their product line. In any case, as these innovations mature, many localized lenders will find returns on all three of the activities undertaken by traditional lenders reduced to an interregionally competitive level. On average, traditional mortgage financing is becoming a less profitable business. This reduced profitability should encourage former mortgage-lending specialists to diversify their product mix into a richer variety of financial services.

\section{Effects on Interest-Rate Spreads}

CMOs and conventional participation certificates differ importantly in taxability. GNMA and Treasury securities differ in callability. When CMOs were first issued, spreads between yields on CMOs and yields on equivalent participation certificates averaged almost 100 basis points. By yearend 1983, the spread seemed to stabilize around 50 basis points. However, in the spring of 1984, the spread widened again but only to about 60 basis points. During the same interval, spreads between GNMA securities and long-term Treasuries declined from over 100 basis points to about 30 basis points. The narrowing of these spreads sharply reduced new issues of MBS.

These developments may be explained by inserting Arrow-Debreu notions of market-completion services into a Marshallian framework for market adjustment. In markets for the input services employed in producing securitized and electronic mortgages, market completion takes the form of unbundling component lender activities and borrower obligations (or of bundling them in combinations not 
previously available): stripping apart origination, servicing, and warehousing functions in mortgage lending as well as the time-dated cash flows and optional features built into a mortgage contract. This stripping parallels the process of breaking butchered chickens apart and reassembling them as packages of homogeneous parts, mainly wings, breasts, and legs (Colton, 1983). Stripping permits the various parts to be priced separately, instead of as a bundle. It may also permit a better price to be collected for "garbage parts" such as gizzards and backs that household customers and restaurants may not value much or at all, by letting butchers wholesale them out to nonhousehold users. With a well-functioning market for chicken parts, manufacturers of dog and cat foods and sausagemakers may purchase supplies of these items in bulk. Who can get the best price for the garbage parts probably determines whether supermarkets or meat processers end up doing the stripping and reassembly. In MBS, for lenders with long maturity habitats, cash flows from mortgage prepayments probably serve as counterparts to undesirable cuts of chicken.

It is instructive to contrast the theoretical short-run, intermediate-run, and long-run effects of such innovations. The Marshallian framework for analyzing economic disequilibrium posits a sequence of temporary equilibria. This theory permits firms that perform the stripping function to earn extranormal profits in the short run, but requires that the intermediate-run and long-run equilibrium price of chickens and MBS be reduced to sum of the new equilibrium prices of the parts. In turn, this sum must equal the average cost of producing, stripping, and repackaging. However, these average costs may vary between the intermediate and long runs.

If the needed stripping and packaging skills are initially in short supply and difficult to acquire quickly, wages paid to strippers and repackagers must be bid up 
temporarily. This occurs in the intermediate run both to encourage entry into stripping and repackaging from allied occupations and to impute excess returns to the temporarily scarce resources involved in the enterprise. During this intermediate run, the costs of stripping and repackaging may exceed their long-run values.

In early 1984, increases in the market value of stripping and packaging skills led Wall Street recruiters to offer dramatic increases in salary to leading finance professors and housing-finance agency personnel to move them into positions in the stripping and repackaging departments of investment-banking firms.

In the long run, like the prices of chickens, the price of CMOs should fall again as returns to human capital in stripping and repackaging adjusted for differences in job security and job satisfaction equalize with those paid in academia and in government-sponsored housing-finance firms.

\section{Effects on Mortgage Borrowers}

Because for the nation as a whole mortgage markets were relatively efficient to begin with, dramatic changes observed in patterns for financing mortgage loans have only minor effects on the typical mortgage borrower. Having one's mortgage incorporated into the collateral pool supporting a mortgage-backed security may marginally reduce the cost of a mortgage loan, but it does not dramatically complicate either the form of mortgage contracts or the nature of contract negotiations. However, prevailing contract forms and the negotiation process itself are being changed by electronic systems for shopping one's mortgage needs across alternative lenders and by the proliferation of contract options.

As extralocal lenders and new forms of mortgage instruments proliferate, mortgage borrowers increasingly feel the need to employ a disinterested financial adviser to help them pick their way through the array of contract interest rates 
and mortgage products offered by different sources. Borrowers recognize that their sketchy prior knowledge of the market value and particular advantages and disadvantages of alternative contract features leave them vulnerable to fasttalking predators. Consumers' growing need for financial planning services opens new product opportunities for displaced mortgage lenders and (among others) enterprising university professors.

\section{Distributional Transition Costs Versus Permanent Efficiency Benefits}

Although transition costs of adapting to technological change impose a distributional burden on transitional mortgage lenders, winners and losers are not foreordained. If savings banks and S\&Ls adapt quickly and appropriately to the new risk-management, mortgage-origination, and mortgage-pooling systems, they can earn much the same profits as nontraditional players can.

Over the long run, innovation in mortgage markets is clearly progressive. It is permanently lightening the pain and drudgery of mortgage contracting and broadening and liquifying secondary and forward markets for mortgages. The result is an increase in the availability and affordability of mortgage funds, a steady expansion in the set of financial functions that a mortgage loan can perform for parties on either side of a mortgage contract, and an increasing demand for expert financial advice. Traditional players that fail to seize the business opportunities these developments provide will be left behind. However, for the permanence of their maladaption, they will have no one to blame but themselves.

\section{Effects on Mortgage Guarantors}

What we may call the dark side of recent changes in mortgage technology concerns increased financial pressure on ill-informed mortgage borrowers and dangers to the stability of the financial system raised by regulatory lags. In the housing-finance system, the risk-bearers of last resort have been slow to appreciate the changing nature of the risks that the new generation of destandardized 
mortgages passes through to them and even slower to take action to bring these risks back under their administrative control.

In mortgage lending, risk-bearers of last resort fall into four categories:

1. Private mortgage insurers (PMIs)

2. Federal deposit-insurance agencies

3. Federally-sponsored mortgage insurers

4. The Fed, the U.S. Treasury, and ultimately the general taxpayer. (These parties explicitly or implicitly ${ }^{5}$ back up the first three sets of insurance providers).

The first three sets of insurers have only recently begun to see that the deepest layers of the inflation risk and interest-volatility risk that destroyed the market value of bookable net worth in the thrift industry and at FNMA during 1965-1982 have not truly been shifted to mortgage borrowers through ARMs. In ARMs, risk shifting remains incomplete for two reasons:

1. Because many ARMs place lifetime and interim caps on the magnitudes of increases in contract interest rates. This means that most of the effects of very sharp swings in interest rates still pass through to lender net worth.

2. Because the FSLIC's stated preference for ARM lending, the thrift industry's depleted capital position, and the massive inflow of FDIC- and FSLIC-subsidized funds into Money Market Deposit Accounts have encouraged a relaxation in underwriting standards that has greatly increased the degree of credit risk in ARM loans.

In a superficially conceived effort to reduce the deposit-insurance subsidy to interest-volatility risk, deposit insurers have encouraged thrifts to make ARMs instead of FRMs. Similarly, until the spring of 1984, mortgage insurers treated ARMs as if these potentially graduated-payment instruments were subject to roughly the same level of default risk as level-payment FRMs. They failed to 
adjust mortgage-insurance premiums and house-appraisal and mortgagor-qualification practices to take account of the distinctly greater dangers of default that are occasioned by the built-in graduated payment shock dictated by sharp first-year interest-rate buydowns and by the possibilities of negative amortization and downward trends in the future price of housing.

As Villani (1984) has emphasized, empirical evidence suggests that the chance of mortgage default rises with the level and volatility of two ratios that are central to any mortgage financing:

1. the ratio of the monthly payment to the borrower's income;

2. the mortgage's loan-to-value ratio.

For this reason, honest measures of these central ratios are critical to determining whether a borrower is qualified for any particular mortgage loan.

With level-payment fixed-rate financing, only the denominator of each ratio is subject to adverse variation: the borrower's income and the value of the home. The monthly payment is fixed and amortization steadily reduces the amount of the outstanding loan. But with adjustable-rate financing, the monthly payment may increase sharply and amortization may turn negative. Moreover, in the environment of the mid-1980s, the value of the collateral may go down as easily as it may go up. During 1965-1980, except for special neighborhood effects, average property values moved favorably.

Given this increase in credit risk, mortgagors, mortgagees, and mortgage insurers need to analyze alternative ARM contracts with great care. This requires access to an appropriate information system and techniques of analysis. None of these parties should make decisions without consulting a reliable advisor possessing good communication skills and access to fast and reliable sof tware.

If borrowers are vulnerable to fast-talking mortgage originators who in the manner of automobile salesmen prey on the unwary, mortgage insurers are, too. In 
Texas, borrowers are reported to have received first-year interest rates bought down as much as eight percentage points. Buydowns of this magnitude tempt a borrower to try to cut the effective return on his loan by taking the initial-period discount and planning to bargain (to the extent that discount points paid at purchase and prepayment penalties allow) for either a fresh buydown or at least a better basic contract rate in a subsequent financing. At the same time, under current appraisal practices, buydowns large enough to tempt borrowers to buy more house than they can afford pass more risk to insurers than they may prefer to take on. Large buydowns tend to be financed by builders and homesellers who want to bid up the transactions price of the house. This lets them transform what would be flows of ordinary income into capital gains on an installment sale. This practice tends to misrepresent the composition of the buyer's equity (by recording the part of a borrower's equity that results from his below-market loan position as an increase in the value of the collateral) and by contributing to an overestimation of the appraised prices of other houses that appraisers may regard as comparable to it.

It is both microeconomically and macroeconomically dangerous to approve contracts whose potential payment shocks are too large for a sizeable proportion of borrowers to handle. In 1983-84, aggregate default risk in ARM loans has risen quickly. Guarantors (private mortgage insurers, FNMA, GNMA, FHLMC, the U.S. Treasury, and ultimately the general taxpayer) are exposed to interest-volatility risk and inflation risk, but now the danger flows not only through the effects of interest and inflation on the capitalized value of mortgagees' holdings of outstanding mortgage loans, but also on their effects on the average rate of mortgagor default. Today, the risk that increases in interest rates and inflation may occasion widespread mortgage defaults is very real.

Because financial analysis ultimately focuses on tradeoffs between risk and return, in evaluating any investment opportunity, two questions predominate: 
1. What are the relevant risks?

2. What return is offered for taking these risks on?

Switching from FRMs to ARMs changes the Treasury's and the taxpayer's ultimate exposure to unpriced interest-volatility and inflation risk frorn mortgage loans a good deal less than a naive observer might suppose. It mainly changes the precise channels through which this risk converges on the Treasury. The capped portion of the risk still falls on deposit insurers. ${ }^{6}$ The uncapped portion of the interest-volatility risk that used to pass directly through thrifts and depositinsurance agencies now flows first through borrowers and private and governmentsponsored mortgage insurers.

ARM riskiness is excessive today because a breakdown in the system of mortgage-market incentives provides unintended government subsidies to mortgage risk. Mispricing Treasury guarantees causes adverse selection by mortgage lenders and mortgage borrowers alike. Mortgage originators, private mortgage insurers, and the government-sponsored mortgage corporations all face incentives that lead them to maximize the volume of business they do and to be careless about certifying and pricing the degree of interest and credit risk in contemporary mortgage loans. S\&L risk-bearing is subsidized by the FSLIC. In setting up to insure GPMs and ARMs, private mortgage insurers carried over experience ratings and qualification practices that were appropriate for level-payment FRMs. The industry's lag in recognizing the need to develop different practices was lengthened by fringe competitors that gambled in a go-for-broke manner on establishing a much-larger foothold in the market.

Risk-taking by PMI managers is encouraged to some degree by their faith that political pressure would lead the Treasury and Federal Reserve to step in to truncate their losses in the event of an industry-wide debacle. In May 1984, this 
faith was reinforced by federal regulators' handling of the crisis at Continental Illinois Bank. If this faith is well-placed, whenever industry leaders adopt a questionable practice, the deepest layers of the resulting PMI risk exposure are shifted implicitly and costlessly to the federal government.

Finally, the government-sponsored mortgage corporations face conflicting incentives. Theirs is a dual mission: to promote home financing and mortgagemarket stability and to earn profits in the process. Because the deepest layers of the portfolio risk that they take is also underwritten by implicit Treasury guarantees that remain unpriced, pursuing large amounts of interest-rate and credit risk improves their prospective rate of return, too. Hence, whenever the net worth of one of these corporations is underwater, its natural reaction is to adopt a riskier investment strategy. It is no accident that, as FNMA's net worth sunk to negative levels, the volume of its mortgage purchases soared.

Policy Remedies: In mortgage markets, the controllability of various subsidies that are built into the regulatory system is reduced by lags in the responses of lenders, MBS packagers, and insurers in the home-finance industry to technological change. Deposit insurers' poorly thought-out efforts to lead thrifts to switch from FRMs to ARMs illustrate the problem and remind me of a story about two lumberjacks. One of them, a man named Random Rates, was always bullying the other. The second lumberjack's name was Fitz (Fitz Lick, actually).

Those of you familiar with the Monty Python song, "I'm a Lumberjack and I'm Okay," know that lumberjacks amuse themselves in odd ways. Because Fitz was a little slow in the brains department, Random had an easy time playing tricks on him. Random's favorite trick was to hold his open hand just in front of a mammoth redwood tree and to dare Fitz to punch the palm of his hand as hard as he could. 
Just as Fitz would release his punch, Random would pull his hand back and Fitz would end up painfully smashing his hand into the tree. (Spectators likened the process to watching Charlie Brown trying to placekick a football out of a hold by Lucy.) After months of watching Fitz injure hirnself in this way, one of the other lumberjacks finally tired of the game and explained to Fitz just how Random was able to slip his punches. Determined to turn the tables on Random, Fitz practiced setting up and pulling his hand away for hours until he had the move down pat. Then, he found Random and proudly dared him to try to land a punch on his hand. As Random wound up to swing at him, a gleeful Fitz eagerly lined up his hand squarely in front of his own face.

The point of the story is that turnabout isn't everything. Shifting interestvolatility risk to borrowers is a lot more easily said than done. To carry out their stabilization mission, housing-finance and deposit-insurance agencies should look for ways to encourage mainstream lenders, appraisers, and insurers to avoid defective qualification and appraisal practices and excessively hazardous mortgage instruments. Specifically, they could take the following steps. First, they might use regulatory pressure and market influence to promote improved qualification and appraisal practices that would discourage excessive buydowns of initial ARM interest rates. Clearly, the artificial inflation of transactions prices in housing caused by interest buydowns does not strengthen the collateral used in qualifying a borrower for a loan. Similarly, in secondary markets careful originators might be encouraged to differentiate their product from that of go-for-broke competitors and to coinsure the loans they sell off under reserve-based arrangements for posting a credible performance bond. Second, governmental and private guarantors and rating agencies might set up systems for identifying lenders and insurers whose operations approach a go-for-broke mode and for imposing an appropriate discount 
or other penalty on the mortgages they bring into secondary markets. This approach could implicitly price the Treasury's unavoidable piece of the overall guarantee action and teach lenders and secondary-rnarket investors to question the effectiveness of guarantees provided by particulary aggressive mortgage-insurance companies. Third, the Administration might draft legislation to price implicit and explicit Treasury guarantees of the performance of mortgage insurers.

\section{Politically Filtered Changes Revisited: The Privatization Issue ${ }^{7}$}

The Reagan Administration has long voiced the suspicion that Fannie Mae, Ginnie Mae, and Freddie Mac unfairly divert secondary-market opportunities away from private firms. Some of the most-prominent arguments cited in support of this position are economically fallacious. They assume that the borrowing undertaken by these federal housing-credit agency-corporations "crowds out" other types of debt. This assumption is fallacious because, as credit intermediaries, these agencies do very little net borrowing. Their portfolio activity serves mainly to arbitrage the cost of credit in different sectors of the capital market. Virtually every dollar they borrow is recommitted in the housing-finance sector of the credit market. However, a logical basis for the Administration's concern lies in exemptions these federal agency-corporations are granted from securities regulations and in their liabilities' receiving valuable explicit and implicit guarantees from the U.S. Treasury without these corporations having to pay an appropriate fee for the value received. 8

If Administration reformers wish to remove the offending subsidies, this could be accomplished in either of two ways. The most straightforward approach would be to eliminate inappropriate burdens that securities regulation of MBS places on private players and to eliminate the Treasury guarantees by recapitaliz- 
ing each corporation as a strictly private entity. Alternatively, Treasury officials could at least endeavor to determine and to collect from each agency-corporation the market value of the Treasury guarantees it enjoys.

The TIMs Question. These conceptually simple approaches must raise unspecified political, bureaucratic, and pricing problems, because Congress has consistently followed the economically less-defensible course of controlling the aggregate size of Treasury guarantees by placing various restrictions on these agency-corporations' asset and liability powers. Continuing this tradition, legislation drafted to broaden opportunities for greater private participation in secondary markets by authorizing the formation of CMO-like "Trusts for Investment in Mortgages" (or TIMs) specifically excludes Mr. Mac and the Mae Sisters from organizing such trusts. This exclusion was intended to impose statutory controls on the mortgage-securitization activities of the agency-corporations. Elements of various bills now before Congress would: authorize the use of a nontaxable trustee; exempt TIMs from SEC registration and net capital requirements imposed on broker-dealers; grant broker-dealers the power to extend credit to purchasers of mortgage-backed securities; allow appropriate investment authority to thrifts and national banks; and preempt state blue-sky laws which might otherwise make it illegal for state-chartered institutions to market private MBS issues.

As a trust, a TIM could not only repartition cash flows from a mortgage pool as a CMO trustee does now, it could also purchase mortgages directly into the trust. Putting mortgages into such trusts takes them completely off the books of originators and, if adopted prior to the 1984 tax act, would have opened up several favorable timing options for taxable investors. Although these tax-timing options are being phased out under the Tax Reform Act of 1984, they would have permitted an investor to use mortgage prepayments and fluctuations in interest rates to lower 
the effective tax rate on the income the mortgage generates by realizing declines in market value as short-term capital losses and taking increases in market value as long-term capital gains (Villani, 1983; Constantinides and Ingersoll, 1983). For whole single-family mortgages and many mortgage participation certificates, even prior to the 1984 tax act, discounts had to be amortized unfavorably as ordinary income and premiums to be amortized unfavorably as capital losses. However, timing options could be claimed both for mortgages on multifamily properties (providing they may be construed to be corporate debt) and for "actively traded" mortgage-backed securities. The latter provision appears to be a loophole inadvertently opened by Title $V$ of The Economic Recovery Tax Act of 1981 in the process of defining rules to govern the tax treatment of straddles. It seems likely that, in an audit situation, the IRS would contest taxpayer attempts to apply this language to ordinary trades.

Most (if not all) of the timing options that would have been opened by TIMs have been rendered moot by the 1984 tax act and in any case already accrue to holders of CMO "bonds." However, TIMs would allow mortgage originators and packagers two other advantages: accounting flexibility as to whether to record an issue of MBS instruments as a liability or an asset sale and tax savings for thrift investors. Unlike CMOs (which are classified as bonds the Financial Accounting Standards Board and by the IRS), thrift-institution investments in a TIM should qualify as mortgage assets under Section 593 of the tax code, which governs favorable tax treatment of transfers to bad-debt reserves. It is more than a little ironic that what is advertised as a technique for getting the government out of the mortgage-subsidization business would increase the flow of tax expenditures to mortgage-lending and mortgage-banking institutions.

Even if these tax expenditures could be determined to be socially desirable, authorizing TIMs is not a necessary condition for their occurrence. It would be 
simpler for Congress merely to define some or all series of CMOs as qualified assets under Section 593. Moreover, Sears Mortgage Corporation maintains that a tax-exempt vehicle for holding assets in trust already exists under current tax law. According to Sears and its affiliated underwriter Dean Witter, interest received by a self-liquidating mortgage trust should not be taxed at the conduit level. Acting on this opinion, Dean Witter formally bought $\$ 1$ billion in GNMA securities for incorporation into self-liquidating trusts. In February 1984, it sold investors $\$ 500$ million of CMO-like multiclass shares in such a trust. When the IRS formally objected to the structure of this deal and proposed to tax such trusts as associations or partnerships, members of the Sears braintrust claimed to be confident that the courts would uphold their interpretation of the tax status of trust income. However, by August 1984, Dean Witter had not shown itself confident enough to issue another round of these securities, as it could have done by promising to compensate investors in the event the courts should rule against their contention. According to the August 13,1984 issue of Bond Week, Dean Witter chose to sell off its second $\$ 500$ million of GNMA securities directly into the market instead.

Privatization versus Economic Efficiency. Economically, the Administration's goal of "privatizing" housing credit need not in itself increase economic efficiency. What could increase economic efficiency would be to place greater reliance on free markets and to identify and to eliminate waste in the operation of federal subsidy programs. Neither of these more-appropriate goals is obviously promoted in the draft legislation on TIMs that the Reagan Administration circulated in February, 1984. The draft bill seeks simultaneously to authorize TIMs and to spare operators of TIMs from having to compete against agency-guaranteed CMOs. The draft plan is to prohibit the future use of CMOs that are supported by mortgage-backed securities issued by federal agencies and to deny FNMA, GNMA, and FHLMC the right to package CMOs of their own.

This proposal goes beyond the fair competitive chance at CMO-type business that financial-industry representatives requested in Congressional hearings last 
yeár (U.S. Senate, 1984). It would actually punish FHLMC for having participated in introducing so successful an innovation as the CMO and hand its share of future business over to tax-exempt copy-cat private competitors.

Barring important competitors is seldom a promising way of establishing economic efficiency. On the contrary, the modern theory of industrial organization emphasizes the desirability of minimizing barriers to entry into any product line in which existing competitors earn above-normal returns.

To make economic sense of the Administration's proposal, we must attribute two assumptions to its architects. First, they must estimate that the value of the Treasury's implicit and explicit guarantees of CMOs is large and hard to price. Second, they must estimate that the disruptive transition costs of terminating a prosperous enterprise in agency CMOs is small.

Data need to be developed on both of these issues. My preliminary judgment is that both assumptions are dangerously false. First, given that a private markets exist both for mortgage insurance and for FNMA stock, pricing out the value of Treasury guarantees of mortgage-backed securities should be a relatively straightforward (albeit tedious) problem. Prohibiting agencies from being active in CMO markets would be far less efficient than charging them the value of the guarantees their activity generates. Moreover, if Treasury guarantees were fully priced, they could be sold directly to private as well as public issuers of MBS. Having to compete against private packagers on an equal basis would let the market determine whether the FNMA, GNMA, and FHLMC could operate efficiently enough to survive.

Second, except for distortions caused by the subsidy to risk-bearing, I believe that the competitive force exercised by the big-three agency-corporations in MBS has been progressive. As potential entrants into any mortgage-related enterprise, 
these arbitrageurs keep morlgage and capital markets closely linked and help to keep local markets for inortgages from departing very far and very long from nationwide competitive norms. While wholly new private entities could develop to perform these same functions, it may be wasteful to incur the transition costs of demolishing a structure that could be brought under market incentives at much lower cost.

\section{A Summary Perspective}

Change is a permanent part of any healthy financial landscape. In fact, the only thing permanent in finance may be the very fact of change. Always on the lookout for instructive metaphors, financial columnists have compared the acceleration of financial change that has occurred in the 1980 s to a revolution. However, because the word "revolution" places the process in a political rather than evolutionary context, I prefer to compare financial change to a biological metamorphosis. Both metaphors dramatize the sharpness of the changes taking place, but they disagree as to the suddenness of the switch and the logical necessity, intelligibility, and manageability of the process involved. Metamorphosis is exemplified by the slow conversion of a caterpillar into a butterfly or the rapid passage of Lon Chaney, Jr. into the Wolfman. A metamorphosis is a predictable and endogenous transformation: a welcome or unwelcome change of form. In contrast, the overthrow of a constitutional government is surprising and organized by disgruntled outside parties plotting in secrecy. In financial change, the disgruntled parties are usually customers and consumerists rather than the innovators, whose interest in building a profitable career leads them to develop new patterns by which to serve these customers.

While incentive problems are raised by regulatory lags in responding to technological developments, financial change is shaped by economic logic rather 
than by political grievances and spreads its shoots gradually through time and space. Reliance on the wrong metaphor has led to the widely voiced impression that political acts of "deregulation" are breaking down established patterns of competition in the U.S. On the contrary, political adjustments in the regulatcry framework are following rather than leading financial change. Moreover, while the precise timing of the various institutional transformations is hard to forecast, the generalized spread of new financial instruments and new patterns of financial competition may be anticipated by any knowledgeable observer and is in fact a source of relatively predictable gains and losses.

Another potentially useful metaphor is that of a geological upheaval: Financial change may be compared to a shift in the terrain of competition. Like a metamorphosis, such shifts are sometimes sudden and sometimes gradual in their development. Although some pre-existing competitors are disadvantaged by the shifting lay of the land, others are strengthened. What matters is not only what happens to the ground one occupies, but also how rapidly a competitor adapts his operations to his altered circumstances and whether the government declares his property part of a disaster area.

Managers who are quick on their feet reap new opportunities, while managers who spend their energy mourning for the good old days typically see their markets transformed away from them. The benefits of the changes discussed in this paper lie principally in opening up markets to new customers and new suppliers. The costs lie in reducing the controllability of pre-existing subsidies to risk-bearing. By facilitating market entry, stripped and electronic mortgage instruments decrease: financial transactions costs, average profit margins, effective tax rates, and the net implicit tax rate that government regulation levies on activities in U.S. financial markets. 


\section{REFERENCES}

Colton, Kent W., "The Role of the Secondary Mortgage Market in Managing Risk," Federal Home Loan Bank of San Francisco Ninth Annual Conference, December 8, 1983.

Constantinides, George M., and Jonathan E. Ingersoll, Jr., "Optimal Bond Trading with Personal Taxes: Implications for Bond Prices and Estimated Tax Brackets and Yield Curves," Working Paper No. 70, Graduate School of Business, University of Chicago (revised April 1983).

Guttentag, Jack M., "Solving the Mortgage-Menu Problem," Housing Finance Review, 2 (July 1983), pp. 227-252.

, "Recent Changes in the Primary Home Mortgage Market," Housing Finance Review, 3 (1984, forthcoming)

Jaffee, Dwight, "The Impact of Financial Futures on Capital Formation," Journal of Futures Market, 5 (Fall 1984; forthcoming).

Kaufman, George G., "The Role of Traditional Mortgage Lenders in Future Mortgage Lending: Problems and Prospects," Housing Finance Review, 3 (1984, for thcoming).

LaGesse, David, "Mortgage Networks Arrange Loans on Computers," The American Banker, Volume 149, January 23, $1984(\mathrm{a})$.

, "FSLIC: Will Back Mortgage Obligations If Issuer Fails," The American Banker, Volume 149, April 3, 1984(b).

, "Kaufman Unveils Builder Bond Plan," The American Banker, Volume 149, June 6, 1984 (c).

Lea, Michael J. and Carolyn Brown, "ARM Pricing: Theory and Practice," Paper presented at the Midyear Meetings of the American Real Estate and Urban Economics Association, Washington, D.C., May 29, 1984.

Schellhardt, Timothy D., "Builders Issuing Bonds to Gain Cheaper Source of Mortgages," Wall Street Journal, October 26, 1983.

Seiders, David F., "Mortgage Pass-Through Securities: Progress and Prospects," Washington, D.C.: Board of Governors of the Federal Reserve System, May $18,1983$.

, "The Future of Secondary Mortgage Markets: Economic Forces and Federal Policies," Housing Finance Review, 3 (1984, for thcoming).

U.S. Senate, Committee on Banking, Housing, and Urban Affairs, Secondary Mortgage Market Enhancement Act of 1983, Hearings before the Sub- 
committee on Housing and Urban Affairs, September 21-22, 1983, Washington: U.S. Government Printing Office, 1984.

U.S. Office of Management and Budget, "Lesiglative Referral Memorandum on Draft Treasury Bill on Trusts for Investments in Mortgages," Washington, D.C.: Executive Office of the President, February 3, 1984.

Villani, Kevin E., "Cash Flow and Risk Arbitrage Opportunities in the Mortgage Securities Markets," Washington,D.C.: Federal Home Loon Mortgage Corpor-
ation, October 28, 1983.

"Innovations in the Mortgage Markets," Everett D. Reese-Park National Bank Distinguished Lectures, Columbus, Ohio, May 24, 1984. 


\section{FOOTNOTES}

'Of course, both the old and the new policy procedures expose the net worth of these institutions to secular deterioration.

2 Similar effects on spot markets for financial instruments from introducing parallel futures markets are discussed in Jaffee (1984).

${ }^{3}$ Guttentag (1984) provides an insightful discussion of the range of features available in destandardized mortgages. Lea and Brown (1984) use data from a Freddie Mac survey of lenders conducted in August and September of 1983 to estimate the yield differentials associated with differential contract features.

${ }^{4}$ Colton (1983) estimates that in June 1983 only 33 percent of the $\$ 158.6$ billion of mortgages traded in the secondary market were purchased by private participants.

5 Implicit guarantees arise out of predictable political pressures for federal authorities to bail out (i.e., truncate the losses of) institutions that fail spectacularly.

${ }^{6}$ Consistent with the view that the deepest layers of interest-rate risk pass on to governmental third parties, FHLMC survey data analyzed by Lea and Brown (1984) indicate that, controlling for other features, caps have an insignificant (and often negative) effect on contract interest rates.

${ }^{7}$ Seiders (1984) also covers this issue.

${ }^{8}$ Moreover, because their arbitrage activity increases the flow of resources toward a tax-advantaged set of investments, even if the federal housing-credit corporations were not subsidized, we could not be sure that their behavior increases economic efficiency. 